Egypt. Acad. J. biolog. Sci., 2 (1):53-61 (2010)

Email: egyptianacademic@yahoo.com

Received: 26/4/2010
F. Toxicology \& pest control

ISSN: 2090 - 0791

www.eajbs.eg.net

\title{
Efficacy of spearmint oil and powder as alternative of chemical control against C. maculatus in Cowpea Seeds
}

\author{
Aly S. Derbalah* and Sahar I. Ahmed \\ Pesticides department faculty of Agriculture kafr-El-Shiekh University, 33516 Egypt \\ E-mail: aliderbalah@yahoo.com
}

\begin{abstract}
Alternative and safe control methods for stored product pests are in demand. Powder and essential oil of Mentha viridis plant leaves were tested under laboratory conditions for its ability to protect cowpea seeds against Callosobruchus maculatus with the respect to adult's mortality, hatchability of laid eggs and emergency of selected insect. Moreover, GC-MS analysis was carried out to identify the possible biologically active components from spearmint oil. Furthermore, the effect of spearmint oil and powder on the germination of cowpea seeds was also investigated. The insect was reared and tested on whole cowpea grain. The efficacy of these plant products was evaluated relative to malathion insecticide as standard compound to protect cowpea grains against $C$. maculatus. The results showed that, the oil and powdered of $M$. viridis were effective against $C$. maculatus insect with the respect to mortality of insect adults. Also, the oil and powdered products of Mentha viridis significantly reduced the number of eggs laid, hatchability and subsequently the emergency of C. maculatus insect relative to control treatment. Slight effect of spearmint products (oil and powder) on the germination of cowpea seeds relative to control was recorded. The efficacy of spearmint oil and powder against the tested insect due to the presence of different compounds that known by its insecticidal activity. The results suggested that, the spearmint oil and powder are promising as alternative of chemical control against $C$. maculatus in cowpea seeds to overcome resistance of the insect against insecticides and reduce the environmental pollution.
\end{abstract}

Keywords: Oil, powder, malathion, cowpea, spearmint plant

\section{INTRODUCTION}

Peas, including cowpea, Vigna unguiculata (L.) Walp. [Leguminosae], are an important staple in worldwide (Rajapakse and van Emden, 1997). A key pest of cowpea is the cowpea weevil, C. maculatus (F.), a bruchid that infests both pods in the field and seeds in storage (Stoll, 1988). According to Singh et al., (1978), 100\% of cowpea seeds are infested after $3 \pm 5$ months of storage. Tanzubil (1991) found that this insect can damage $100 \%$ of stored seeds causing weight losses of up to $60 \%$. After six months of storage, losses in terms of perforated seeds can reach 90\% (Seck et al., 1991). Control of stored-product insect populations is primarily dependent upon continued applications of liquid and gaseous insecticides (White and Leesch, 1995). Although its efficiency, their repeated use for several decades has disrupted biological control system by natural enemies and led to outbreaks of insect pests, widespread development of resistance, undesirable effects on non-target organisms, and environmental and human health concerns (Champ and Dyte, 1977; Subramanyam et al., 1994; White and Leesch, 1995). Furthermore, the indiscriminate use of pesticides by farmers and traders to keep bruchids under control has given rise to an urgent need to develop ecologically safer and sounder pest control techniques that must also be economic, simple and practical (Rajapakse, 1990). Grain legumes in tropical markets are often sold by volume, which is not reduced by bruchid attack (Wegmann, 1983). For these reasons there is scope for control techniques that are less effective than insecticides. Synthetic insecticides are expensive for 
subsistence farmers and they may pose potential risks owing to the lack of adequate technical knowledge related to their safe use. One alternative to synthetic insecticides is insecticidal plants (Thiam and Ducommun, 1993). Oils extracted from plants have been extensively used for crop protection (e.g. Singh et al., 1978; Rajapakse and van Emden, 1997).

The use of plant materials can lead to the identification of new bio-insecticides for the benefit of tropical agriculture. Essential oils for instance have been widely tested and have given promising results under laboratory conditions (Isman, 2000; Regnault-Roger, 1997). They have shown strong insecticidal activity against bruchid pests (Rahman and Schmidt, 1999; Glitho et al., 1997; Shaaya et al., 1997; RegnaultRoger and Hamraoui, 1993). These oils can be obtained by steam distillation of plant materials and their exploitation can be a source of income for farmers (Ketoh et al., 2000). Some are non-toxic to mammals and non-persistent in water and soil (Misra and Pavlostathis, 1997).

The use of plant materials can lead to the identification of new bio-insecticides for the benefit of tropical agriculture. Therefore, the present study attempted to evaluate the efficiency of spearmint oil and powder relative to recommended compound malathion against $C$. maculatus insect with the respect to adults mortality and progeny of the selected insect, to identify the chemical components of spearmint oil that may be responsible to its insecticidal activity against C. maculatus and finally to investigate the effect of spearmint oil and powder on the germination of cowpea seeds.

\section{The insect \\ MATERIALS AND METHODS}

C. maculatus (Egyptian strain) was obtained from the Department of Stored Product Pests Control, Research Institute of Plant Protection, and Sakha Kafr-El-shiekh. This strain was continuously reared free of insecticidal contamination for several years at $30 \pm 2{ }^{\circ} \mathrm{C}$ and $70 \pm 5$ r.h. relative humidity. The culture was raised by infesting 30 pairs of newly emerged C. maculatus adults into $500 \mathrm{gm}$ of cowpea in large box and kept under laboratory condition in the Pesticide Department, Faculty of Agriculture, and
Kafr-El-shiekh University, Egypt. After, 35 d newly emerged (F1) adults were collected and used to infest the cowpea samples.

\section{The stored product}

Cowpea seeds (V. unguiculata (L.) Walp.) were used to culture C. maculatus. Cowpea seeds were stored in airtight tins until needed for experiments which were carried out in a constant temperature room maintained at $25^{\circ} \mathrm{C}$ and $70 \%$ r.h.

\section{The plant products}

Powdered and oil products of spearmint plant leaves were obtained from a local supermarket.

Effect of spearmint plant (oil and powdered) and malathion on some biological activities of $C$. maculatus.

Ten gm of cowpea seeds were treated with spearmint oil dissolved in acetone at concentration levels of 100, 200 and 300 $\mathrm{ppm}$ for each to evaluate its efficiency against C. maculatus. The treatment was carried out by addition of $2 \mathrm{ml}$ of each concentration and mixed will with $10 \mathrm{gm}$ of cowpea seeds and after acetone evaporation, the cowpea seeds were transferred in an $85 \mathrm{x}$ $45 \mathrm{~mm}$ plastic jar. Malathion was applied in the same manner of spearmint oil but at concentration levels of 3,6 and $12 \mathrm{ppm}$. However for spearmint powder, ten gm of cowpea seeds were mixed with spearmint powder at concentration levels of $0.5,1$ and $1.5 \% \mathrm{w} / \mathrm{w}$. The cowpea seeds were shaken thoroughly to ensure uniform coverage by the different treatments and transferred in an $85 \times 45 \mathrm{~mm}$ plastic jar. Each concentration was applied in three replicates, and each replicate consisting of $10 \mathrm{gm}$ cowpea seeds in an $85 \times 45 \mathrm{~mm}$ plastic jar. The control treatment was carried using water and replicated three times. Then, 10 adults males and females of C. maculatus were transferred to treated cowpea seeds and kept at $30 \pm 2 \mathrm{C}^{\circ}$ and $70 \pm 5$ r.h. relative humidity, according to the method described by Ahmed (2007). The total number of eggs laid was recorded after five days of treatment and then after one week the number of eggs hatched was recorded. Hatchability, emergency and reduction percentages were calculated as shown in equations 1,2 and 3 as described by El-Lakwah et al., (1992). Moreover, the weight loss of wheat grains due to infestation with C. maculatus was determined 6 weeks after treatment by 
sieving the insects from grains, then the \% loss was calculated as shown in eq (4) described by Harris and Lindblad (1978).

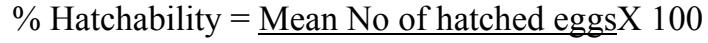
Mean No. of egg laid

$\%$ Emergency $=\underline{\text { Mean No of emerged adults }}$ X 100 Mean No. of egg laid

$\%$ Reduction $=\underline{\text { MNEC-MNET } /} \times 100$ MNEC

MNEC $=$ Mean No. of emerged in control

MNET $=$ No of emerged in treatment

$\%$ Loss $=$ IDWG - GDWW / IDWG x 100

*IDWG $=$ initial dry weight of grains

*GDWW= grains dry weight after 6 weeks

Efficiency of spearmint plant (oil and powdered) and malathion on of $C$. maculatus beetle by mean mortality.

Ten gm of cowpea seeds were treated with spearmint oil dissolved in acetone at concentration levels of 100, 200 and 300 ppm for each to evaluate its efficiency against C. maculatus. The treatment was carried out by addition of $2 \mathrm{ml}$ of each concentration and mixed will with $10 \mathrm{gm}$ of cowpea seeds and after acetone evaporation, the cowpea seeds were transferred in an $85 \mathrm{x}$ $45 \mathrm{~mm}$ plastic jar. Malathion was applied in the same manner of spearmint oil but at concentration levels of 3,6 and $12 \mathrm{ppm}$. However for spearmint powder, ten gm of cowpea seeds were mixed with spearmint powder at concentration levels of $0.5,1$ and $1.5 \% \mathrm{w} / \mathrm{w}$. The cowpea seeds were shaken thoroughly to ensure uniform coverage by the different treatments and transferred in an 85 × $45 \mathrm{~mm}$ plastic jar. Each concentration was applied in three replicates, and each replicate consisting of $10 \mathrm{gm}$ cowpea seeds in an 85 x $45 \mathrm{~mm}$ plastic jar. The control treatment was carried using water and replicated three times. Then, 10 adults males and females of C. maculatus were transferred to treated cowpea seeds and kept at $30 \pm 2 \mathrm{C}^{\circ}$ and $70 \pm 5$ r.h. relative humidity, according to the method described by Ahmed (2007). The glass jars were covered with cotton cloths held with rubber bands. The number of dead insects in each jar was counted after one weeks of treatment. The percentage of insect mortality was calculated

RESULTS

Effect of spearmint plant (oil, powder) and malathion on oviposiblity, and then corrected using the Abbott formula (1925). The regression lines were statistically analyzed according to Lichfield and Wilcoxon (1949) and $\mathrm{LC}_{50}$ values were calculated.

\section{Chemical composition of essential oils in Mentha viride plant}

GC/MS analysis was conducted on a HP 6890 GC system coupled with a 5973 network mass selective detector with a capillary column of HP-5MS $(60 \mathrm{~m} \times 0.25 \mathrm{~mm}$, film thickness $0.25 \mathrm{~m}$ ). The oven temperature program was initiated at $40{ }^{\circ} \mathrm{C}$, held for 1 min then raised up to $230^{\circ} \mathrm{C}$ at a rate of $3^{\circ} \mathrm{C}$ $/ \mathrm{min}$ held for $10 \mathrm{~min}$.Helium was used as the carrier gas at a flow rate $1.0 \mathrm{ml} / \mathrm{min}$, with a split ratio equal to $1 / 50$, injector and The detector and injector temperatures were 250 and $230{ }^{\circ} \mathrm{C}$, respectively. The compounds of the oil were identified by comparison of their retention indices (RI), mass spectra fragmentation with those on the stored Wiley 7n.1 mass computer library, and NIST (National Institute of Standards and Technology) (Mahboubi and Haghi, 2008) . The samples were analyzed in the central laboratory for pesticides, Agriculture Research Centre, Egypt.

Effect of the tested products on the germination of cowpea seeds

The effect of spearmint oil ,powder and malathion on the germination of cowpea seeds was tested. Cowpea seeds were treated with spearmint oil, powder and malathion at the different tested concentration levels. After one month of treatment with the tested products, $10 \mathrm{gm}$ of cowpea seeds were transferred to cotton saturated with water in Petri dishes and germination percentages were recorded by counting the number of germinated and non-germinated cowpea seeds relative to control treatment (water only).

\section{Statistical treatment}

Data were analyzed statistically by the analysis of variance test and the different means were compared by Duncan's multiple range test.

\section{hatchability and emergency of $C$. maculatus adults.}

The numbers of eggs laid, eggs hatched and emerged adults as a percentage of the control, were significantly decreased in all 
treatments (spearmint oil, powder and malathion) as shown in Table 1 . The reduction in the number of eggs laid after treatment with botanical products and malathion were concentration dependent.
Among the tested products, malathion was the most effective treatment in reducing eggs laid followed by spearmint powder and oil, respectively.

Table 1: Effect of spearmint oil, powder and malathion on hatchability and emergency of C.maculatus.

\begin{tabular}{|l|l|l|l|l|}
\hline Treatment & $\begin{array}{c}\text { Concentration } \\
\text { level }\end{array}$ & No of eggs laid & $\%$ Hatchability & \% Emergency \\
\hline \multirow{3}{*}{ Spearmint oil } & $100 \mathrm{ppm}$ & $185 \mathrm{~b}$ & $59.5 \mathrm{~b}$ & $37.2 \mathrm{c}$ \\
\cline { 2 - 5 } & $200 \mathrm{ppm}$ & $128 \mathrm{c}$ & $35.2 \mathrm{c}$ & $31 \mathrm{~d}$ \\
\cline { 2 - 5 } & $300 \mathrm{ppm}$ & $98 \mathrm{f}$ & $32.6 \mathrm{e}$ & $28 \mathrm{~d}$ \\
\hline \multirow{3}{*}{ Spearmint powder } & $100 \mathrm{ppm}$ & $122 \mathrm{~d}$ & $37.7 \mathrm{c}$ & $54.3 \mathrm{~b}$ \\
\cline { 2 - 5 } & $200 \mathrm{ppm}$ & $105 \mathrm{e}$ & $33.3 \mathrm{~d}$ & $34 \mathrm{~d}$ \\
\cline { 2 - 5 } & $300 \mathrm{ppm}$ & $39 \mathrm{~g}$ & $25.6 \mathrm{f}$ & $00 \mathrm{e}$ \\
\hline \multirow{3}{*}{ Malathion } & $3 \mathrm{ppm}$ & $32 \mathrm{~h}$ & $15.6 \mathrm{~g}$ & $00 \mathrm{e}$ \\
\cline { 2 - 5 } & $6 \mathrm{ppm}$ & $5 \mathrm{i}$ & $00 \mathrm{i}$ & $00 \mathrm{e}$ \\
\cline { 2 - 5 } & $12 \mathrm{ppm}$ & $0 \mathrm{j}$ & $00 \mathrm{i}$ & $96.5 \mathrm{a}$ \\
\hline Control & 0.00 & $285 \mathrm{a}$ & $94.7 \mathrm{a}$ & $\mathrm{e}$ \\
\hline
\end{tabular}

The reduction in the emerged adults of the tested insect was concentration dependent at all tested treatments and there were significant differences among the concentration levels of each treatment. Malathion was the most effective treatment in reducing emergency followed by spearmint powder and oil, respectively as shown in Fig.1. Mint powder was more effective than mint oil against $C$. maculatus weevil at all tested parameters (eggs laid, hatchability and emergency).

The loss rate in cowpea seeds weight after 6 weeks of treatment was decreased with the increasing of the concentration level of spearmint oil, powder and marathon as shown in Table 2. The rate of loss in cowpea seeds weight was significantly decreased in all tested treatments relative to control. Malathion recorded the lowest loss rate in cowpea seeds weight relative to other treatment followed by spearmint oil and powder, respectively. Since the highest concentration of spearmint powder, oil and malathion gained no loss in cowpea seeds weight.

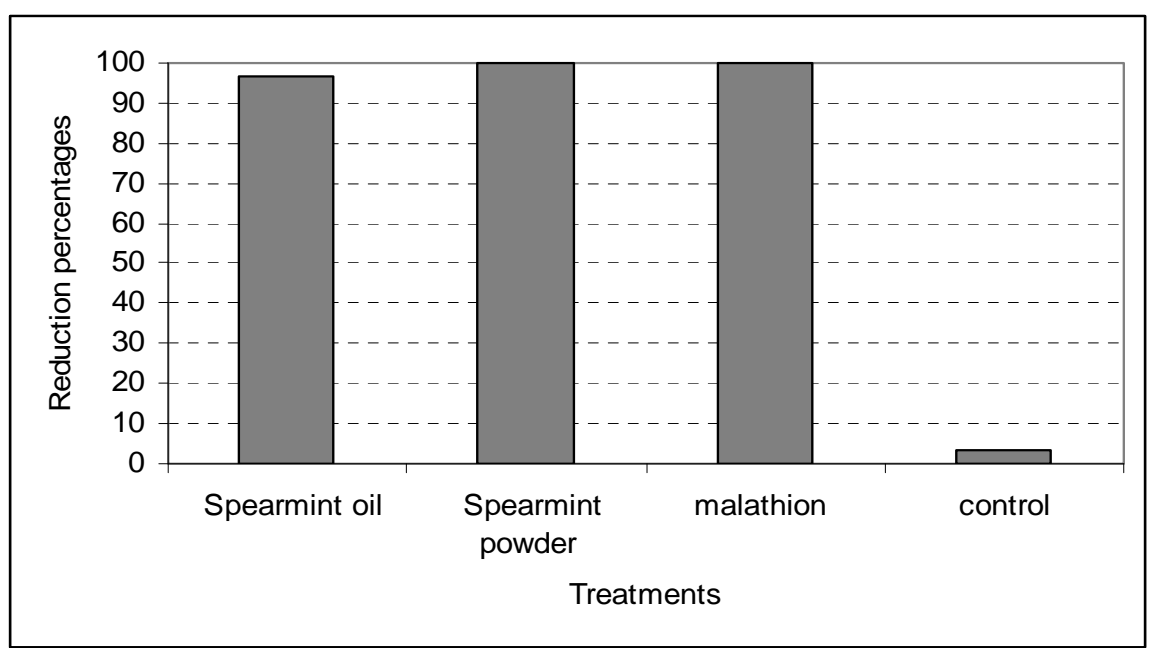

Fig. 1: Effect of spearmint oil and powder as well as malathion at the highest applied concentration on the progeny of C.maculatus relative to control 
Table 2: Effect of spearmint oil, powder and malathion on loss rate of cowpea seeds relative to control.

\begin{tabular}{|c|c|c|}
\hline \multirow{2}{*}{ Treatment } & $\begin{array}{c}\text { Concentration } \\
\text { level }\end{array}$ & $\%$ of cowpea seeds loss \\
\hline \multirow{3}{*}{ Spearmint oil } & $100 \mathrm{ppm}$ & $8.0 \mathrm{~b}$ \\
\cline { 2 - 3 } & $200 \mathrm{ppm}$ & $5.0 \mathrm{c}$ \\
\cline { 2 - 3 } & $300 \mathrm{ppm}$ & $0.00 \mathrm{f}$ \\
\hline \multirow{2}{*}{ Spearmint powder } & $100 \mathrm{ppm}$ & $10 \mathrm{~b}$ \\
\cline { 2 - 3 } & $200 \mathrm{ppm}$ & $5.0 \mathrm{c}$ \\
\cline { 2 - 3 } & $300 \mathrm{ppm}$ & $0.4 \mathrm{~d}$ \\
\hline Malathion & $3 \mathrm{ppm}$ & $5.0 \mathrm{c}$ \\
\cline { 2 - 3 } & $6 \mathrm{ppm}$ & $4.5 \mathrm{c}$ \\
\cline { 2 - 3 } & $12 \mathrm{ppm}$ & $0.00 \mathrm{f}$ \\
\hline Control & 0.00 & $30 \mathrm{a}$ \\
\hline
\end{tabular}

Efficiency of spearmint products (oil indicated that, malathion was the most and powder) and malathion on of $C$. effective treatment against the tested maculatus beetle by mean mortality.

The mortality percentages of $C$. maculatus adults after treatment with malathion, as well as spearmint powder and oil were shown in Table 3 . The result insect followed by spearmint oil and powder, with $\mathrm{LC}_{50}$ values of 8.7, 235 and $276 \mathrm{ppm}$, respectively. Spearmint oil was more effective than spearmint powder against $C$. maculates adults.

Table 3: Effect of spearmint oil, powder and malathion as protectant on adult mortality of C.maculatus after one week.

\begin{tabular}{|l|c|c|c|}
\hline Treatment & LC $_{50}$ & Upper & Lower \\
\hline Malathion & 8.77 & 1.34 & 0.35 \\
\hline Spearmint oil & 235 & 277 & 192 \\
\hline Spearmint powder & 276 & 329 & 225 \\
\hline
\end{tabular}

\section{Chemical components of spearmint oil}

The GC-MS analysis of the spearmint oil yielded thirteen main volatile compounds representing $96 \%$ of the oil content. The compounds were identified as alpha pinene, beta pinene, cineole, limonene, methone, menthal, pulegone, bronyl acetate, menthyl, caryophyllene, eicosane, heneicosane and docosane as shown in Table 4. The identified compounds were belonging to eldyhydes, esters, alcohols and fatty acids. The GC-MS separated compounds were identified from the recorded mass spectra by comparison with the mass spectra from the Wiley library.

Table 4: The main constituents of spearmint oil

\begin{tabular}{|l|c|c|c|}
\hline \multicolumn{1}{|c|}{ Identified Compounds } & Retention time & $\begin{array}{c}\text { Percentage } \\
(\%)\end{array}$ & Main m/z ions \\
\hline Alpha pinene & 9.64 & 8.95 & $93-77$ \\
\hline Beta pinene & 11.6 & 2.59 & $93-69-77$ \\
\hline 1,8 Cineole & 14.75 & 17.32 & $93-68$ \\
\hline Limonene & 14.80 & 18.20 & $108-81$ \\
\hline Menthone & 23.01 & 16.11 & $112-69-139$ \\
\hline Menthal & 23.5 & 21.81 & $112-69-139$ \\
\hline Pulegone & 28.31 & 1.04 & $81-152-67$ \\
\hline IsobBronyl acetate & 31.21 & 5.16 & $95-136-121$ \\
\hline Menthyl acetate & 31.81 & 5.79 & $81-138-95$ \\
\hline Caryophyllene & 39.10 & 0.41 & $133-161-93$ \\
\hline Eicosane & 70.85 & 1.04 & $57-71-85$ \\
\hline Heneicosane & 75.15 & 0.61 & $57-71-85$ \\
\hline Docosane & 79.53 & 0.47 & $57-71-85$ \\
\hline
\end{tabular}


Effect of the tested products on the germination of cowpea seeds

The germination percentage of wheat grains after one month of treatment with malathion, powder, and oil of spearmint plant were shown in Table 5. The results indicated that, there were slight effects in the germination of wheat grains in all treatments relative to control. Moreover, spearmint oil was the highest treatment that reduced the germination percentage of wheat grains followed by spearmint powder and malathion, respectively. The inhibition in germination percentage of wheat grains was positively correlated with concentration level of all the tested treatments since there was significant difference among the concentration levels of each treatment.

Table 5: Effect of spearmint oil, powder and malathion on germination of cowpea seeds after one month of treatment.

\begin{tabular}{|l|c|c|}
\hline Treatments & Concentration & \% Germination \\
\hline \multirow{3}{*}{ Spearmint oil } & $100 \mathrm{ppm}$ & $85 \mathrm{~d}$ \\
\cline { 2 - 3 } & $200 \mathrm{ppm}$ & $95 \mathrm{~b}$ \\
\cline { 2 - 3 } & $300 \mathrm{ppm}$ & $100 \mathrm{a}$ \\
\hline \multirow{3}{*}{ Spearmint powder } & $100 \mathrm{ppm}$ & $77.5 \mathrm{e}$ \\
\cline { 2 - 3 } & $200 \mathrm{ppm}$ & $92.5 \mathrm{c}$ \\
\cline { 2 - 3 } & $300 \mathrm{ppm}$ & $97.5 \mathrm{a}$ \\
\hline \multirow{2}{*}{ Malathion } & $3 \mathrm{ppm}$ & $97.5 \mathrm{a}$ \\
\cline { 2 - 3 } & $6 \mathrm{ppm}$ & $100 \mathrm{a}$ \\
\cline { 2 - 3 } & $12 \mathrm{ppm}$ & $100 \mathrm{a}$ \\
\hline Control & 0.00 & $100 \mathrm{a}$ \\
\hline
\end{tabular}

\section{DISCUSSION}

The results of the present study implied that the tested spearmint oil and powder were effective against $C$. maculatus in stored cowpea with the respect to progeny and adults mortality. The efficacy of spearmint oil and powder against $C$. maculatus insect in stored wheat with the respect to progeny and adult morality have been reported by many researchers ( Raja et al., 2001 Tapondjou et al., 2002 ; Ketoh et al., 2005).

The study has also shown that spearmint oil was significantly more effective against $C$. maculatus with the respect to adult mortality and emergency than spearmint powder. It has been reported that one of the main mechanisms of action of plant oils is their ability to penetrate the chorion of bruchid eggs via the micropyle and cause the death of developing embryos through sphyxiation (Credland, 1992). This may be one of the reasons why spearmint oil caused considerably higher reductions of adult emergency than spearmint oil. Also, the high efficacy of spearmint oil than powder against $C$. maculatus may be due to the high penetration ability of oil to insect body than powder. Reduction of adult emergence may have been achieved through a combination of high mortality of eggs and larvae immediately after eclosion and contact with spearmint oil (Lale and Abdulrahman 1999).

The tested spearmint oil and powder especially oil showed high efficacy against $C$. maculatus in stored cowpea with the respect to progeny and adults mortality same as or near the recommended chemical compound malathion. This is suggests the ability of using these botanical products as alternative of chemical control of stored product pests such as C. maculatus. This approach can contribute in reducing the amount applied of pesticides and subsequently minimize its hazards to the environment and human health and also overcome the problem of resistance development by insect against chemical pesticides.

The identified compounds by GCMS in this study agree with those identified in other studies (Franzios et al. 1997; Gherman et al., 2000; Chauhan et al., 2009). Among the identified 
compounds, Alpha pinene (8.95\%), 1,8 Cineole $(17.32 \%)$, Limonene $(18.2 \%)$, and Menthal (21.81\%) were detected with higher percentages relative to other detected compounds. These compounds may be the responsible for insecticidal activity of spearmint oil and powder recorded against the tested insecticide in this study (Franzios et al. 1997; Gherman et al., 2000; Lee et al., 2000). Although, the insecticidal activity of spearmint oil and powder is attributed mainly to its major compounds mentioned before, the synergistic or antagonistic effect of one compound in the mixture has to be considered. Each of the components has its own contribution on biological activity of the extract. For example pulegone detected with low percentage but it is known to possess diverse biological properties, such as insect repellant (Gordon et al., 1982).

The mode of action of bioactive natural monoterpinoids (hydrocarbons, alcohols and ketones) from spearmint oils may be due to inhibition of acetylcholinestearase (Miyazawa et al., 1997; Lee et al., 2000). Since Lee et al. (2000) reported that, 1,8-Cineole was the most potent inhibitor of eel AChE among the monoterpenes tested. This inhibition may be a mode of action for essential oil and monoterpene fumigation toxicity against stored grain insect pests as well. Also, the insecticidal mode of action of the compounds in spearmint may be largely attributable to fumigant action they may be toxic by penetrating the insect body via the respiratory system (Shaaya et al., 1997; Park et al., 2003).

The essential oils as pest control agent present two main characters: the first is their natural origin which means more safety to the people and the environment and the second is that they have be considered at low risk for resistance development by stored products insects. It is believed that it is difficult for the insect to develop resistance to such a mixture of components with, apparently, different mechanisms of pesticidal activity. This study considered the first step toward more investigation and concern about using these effective botanical extracts for control different pests as alternative for chemical control which in return help to reduce the environmental pollution and the adverse effect on human health resulted from pesticides uses.

\section{CONCLUSIONS}

The insecticidal activity of the spearmint products against $C$. maculatus insect indicated the potential of using it as a natural source of insecticidal material. Insecticidal activity was confirmed in oil and powder of spearmint, although the results showed that oil and powder of spearmint varied in their effectiveness against $C$. maculatus insect. The ability of using botanical products as alternative of chemical control of C. maculatus insect is possible. The GC-MS analysis of the spearmint oil indicated the presence of different biologically active compounds would be more effective to control stored products insects and less likely to select for resistance than synthetic fungicides that composed of a single compound. This approach can contribute in reducing the amount applied of insecticides and subsequently minimize its hazards to the environment and human health. Work in this regards should continue on other invasive species on isolating insecticidal compounds and on field trials with promising extracts or compounds. Further research is needed in order to obtain information regarding the practical effectiveness of essential oils to protect the stored products without any side effects.

\section{REFERENCES}

Abbott, W.S. (1925). A method of computing the effectiveness of an insecticide. Journal of Economic Entomology 18: 265-267.

Ahmed, S.I. (2007) Atmospheric modification as a new approach for controlling stored 
grain pests. PhD Thesis. Fac. of Agric.

Kafr-El-Sheikh University pp 122.

Champ, B.R. and Dyte, C.E. (1977). FAO global survey of pesticide susceptibility of stored grain pests. FAO Plant Protection Bulletin 25: 49-67.

Chauhan, R.S.; Kaul, M.K.; Shahi, A.K.; Kumar, A.; Ram, G. and Tawa, A. (2009). Chemical composition of essential oils in Mentha spicata L.accession [IIIM(J)26] from North-West Himalayan region,India. Industrial Crops and Products 2 9: 654-656.

Credland, P.F. (1992). The structure of bruchid eggs may explain the ovicidal effect of oils. Journal of Stored Products Research 28: 1-9.

El-Lakwah, F. A.; Darwish, A. A. Khaled, O.M. (1992). Effectiveness of Dill seed powder on stored products insects. Ann. Agric. Sc. Moshtohor 34: 2031-2037.

Franzios, G.; Mirotsou, M.; Hatziapostodou, J.; Scouras, Z. and Mavaragani-tsipidou P. (1997). Insecticidal and genotoxic activities of mint essential oils. J. Agric. Food Chem. 45: 2690-2694.

Gherman, C.; Culea, M.and Cozar, O. (2000). Comparative analysis of some active principles of herb plants by GC:MS Talanta 53: 253-262

Glitho, I.A.; Ketoh, G.K.and Koumaglo, H.K. (1997). Effects de quelques huiles essentielles sur l'activit!e reproductive de Callosobruchus maculatus Fab. Annales de l'Universit!e de Ouagadougou 5: 174-185.

Gordon, W.P.; Forte, A. .J.; McMurthy, R. J.; Gal, J. and Nelson, S.D. (1982). Toxicol Appl Pharmacol 65: 413.

Harris, K. and Lindblad, C.S. (1978). Postharvest grain loss assessment method. Cereal Chem. St. Paul 193.

Isman, M.B. (2000). Plant essential oils for pest and disease management. Crop Protection 19: 603-608.

Ketoh, G.K.; Glitho, I.A.; Koumaglo, H.K. and Garneau, F.X. (2000). Evaluation of essential oils from six plants in Togo for Callosobruchus maculatus F. pest control. Insect Science and its Application 20: 45-49.

Ketoh, G.K.; Koumaglo, H.K.; Isabelle, A.and Glitho, I. A. (2005). Inhibition of Callosobruchus maculates (F.) (Coleoptera:Bruchidae) development with essential oil extracted fromCymbopogon schoenanthus L. Spreng. (Poaceae), and the wasp Dinarmus basalis (Rondani)
Hymenoptera: Pteromalidae)Journal of Stored Products Research 41: 363-371.

Lale, N.E.S. and Abdulrahmanb, H.T. (1999). Evaluation of neem (Azadirachta indica A. Juss) seed oil obtained by di.erent methods and neem powder for the management of Callosobruchus maculatus (F.) (Coleoptera: Bruchidae) in stored cowpea. Journal of Stored Products Research 35: 135-143.

Lichfield, J.T. and Wilcoxon,W. (1949) A simplified method of evaluated doseeffect experiments. Journal of pharmacology Experiments therapy 96: 99-113.

Mahboubi, M. and Haghi, G. (2008) . Antimicrobial activity and chemical composition of Mentha pulegium L. essential oil. Journal of Ethnopharmacology 119: 325-327.

Misra, G. and Pavlostathis, S.G. ( 1997). Biodegradation kinetics of monoterpenes in liquid and in a soil-slurry system. Applied Microbiological Biotechnology 47: 572-577.

Miyazawa, M.; Watanabe, H. and Kameoka, H. (1997). Inhibition of acetylcholinesterase activity by monoterpenoids with a pmenthane skeleton J. Agric. Food Chem. 45: 677-679.

Rahman, M.M. and Schmidt, G.H. (1999). Effect of Acorus calamus essential oil vapours from various origins on Callosobruchus phaseoli. Journal of Stored Products Research 35: 285-295.

Raja. N.; Albert, S.; Ignacimuthu, S. and Dorn, S. (2001). Effect of plant volatile oils in protecting stored cowpea Vigna unguiculata (L.) Walpers against Callosobruchus maculatus (F.) (Coleoptera: Bruchidae) infestation. Journal of Stored Products Research 37: 127-132

Regnault-Roger, C. (1998). The potential of botanical essential oils for insect pest control. Integrated Pest Management Reviews 2: 25-34.

Regnault-Roger, C.; Hamraoui, A.; Hotelman, M.; Theron, E. and Pineal, R. (1993). Insecticidal effect of essential oils from Mediterranean plants upon Acanthoscelides obtectus Say (Coleoptera, Bruchidae), a pest of kidney bean (Phaseolus vulgaris L.). Journal of Chemical Ecology19: 1233-1244.

Rajapakse, R. and van Emden, H.F. (1997). Potential of four vegetable oils and ten botanical powders for reducing infestation of cowpea by Callosobruchus maculatus, C. chinensis and $C$. 
rhodesianus. Journal of Stored Products Research 33: 59-68.

Park, K.; Leeb,S.G.; Choib, D.H.; Park,J. and Young-Joon A. (2003). Insecticidal activities of constituents identified in the essential oil from leaves of Chamaecyparis obtusa against Callosobruchus chinensis (L.) and Zoophiles oryzae (L.) Journal of Stored Products Research 39: 375-384.

Seck, D.; Sidibe, B.; Haubruge, E.; Hemptinne, J.L. and Gaspar, C. (1991). La protection chimique des stocks de nieÂbe $\hat{A}$ et de maõÈs contre les insectes au SeÂneÂgal. Medelingen van de Faculteit Landbouwwetenschappen

Rijksuniversiteit Gen 56/3b, 1225-1234.

Shaaya, E.; Kostjukovski, M.; Eilberg, J.and Sukprakarn, C. (1997). Plant oils as fumigants and contact insecticides for the control of stored-product insects. Journal of Stored Products Research 33: 7-15.

Singh, S.R.; Luse, R.A.; Leuschner, K. and Nangju, D. (1978). Groundnut oil treatment for the control of Callosobruchus maculatus (F.) during cowpea storage. Journal of Stored Products Research 14: 77-80.

SPSS for Windows 7.0 (1995). December 19, Network Version, SPSS Inc. 1989-1995.

Stoll, G., 1988. Protection naturelle des veÂgeÂtaux en zones tropicales. CTA; AGRECOL, 177 pp.
Subramanyam, B.H.; Swanson, C.L.; Madamanchi, N. and Norwood, S. (1994). Effectiveness of Insector, a new generation diatomaceous earth formulation, in suppressing several stored insect species. In: Highley, E., Wright, E., Banks, H.J., Champ, B.R. (Ed.). Proceedings of the 6th International Working Conference on Stored-Product Protection, Canberra, Australia, 2: 650-659.

Tanzubil, P.B. (1999). Control of some insect pests of cowpea (Vigna unguiculata) with neem (Azadirachta indica A.Juss.) in Northern Ghana. Tropical Pest Management 37: 216-217.

Tapondjou, L.A.; Adler, C.; Bouda, H. and Fontem, D.A. 2002. Efficacy of powder and essential oil from Chenopodiumam brosioides leaves as post-harvest grain protectants against six-stored product beetles. Journal of Stored Products Research 38: 395-402

Thiam, A., Ducommun, G. (Eds.), (1993) Protection naturelle des veÂgeÂtaux en Afrique. EÂ ditions Enda, Dakar,SeÂnê̂̀ gal.

White, N.D.G. and Leesch, J.G. (1995). Chemical control. In: Subramanyam, B., Hagstrum, D.W. (Eds.), Integrated Management of Insects in Stored Products. Marcel Dekker, New York, pp. 287-330.

\section{ARABIC SUMMARY}

\footnotetext{
تقييم كفاءة مسحوق وزيت النعناع فى مكافحة حشرة خنفساء الوبيا كبدائل امنه للمكافحة الكيميائية

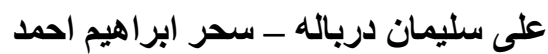

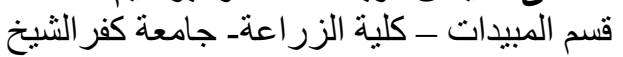

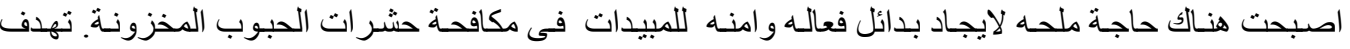

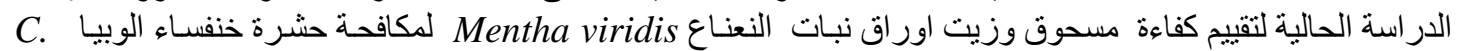
maculatus

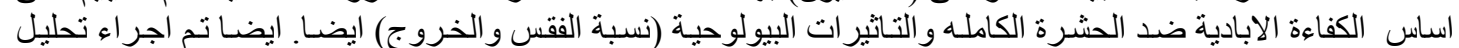

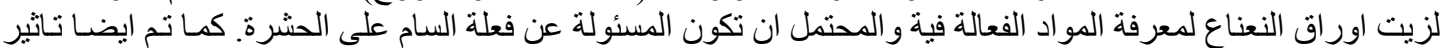

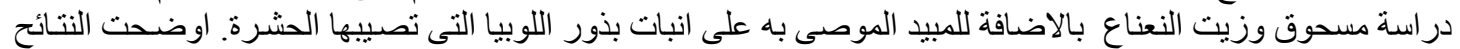

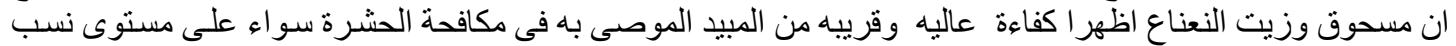

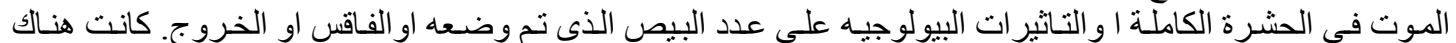

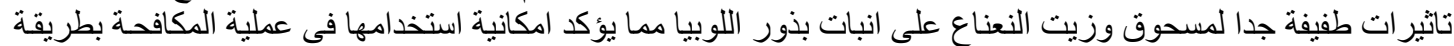

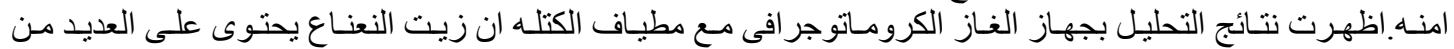

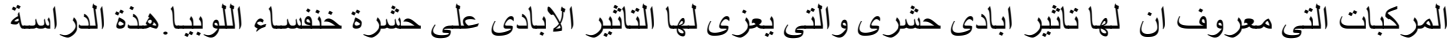

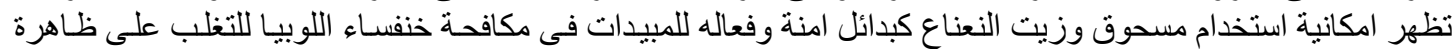

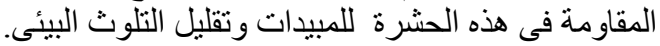

